\title{
ENTEROCOCCUS DURANS İLE EKSTRASELÜLER LİPAZ ÜRETİMİ VE KAREKTERIZZASYONU
}

\author{
Esra Acu, Volkan Kılıç, Merih Kıvanç* \\ Eskişehir Teknik Üniversitesi Fen Fakültesi Biyoloji Bölümü, Eskişehir, Türkiye.
}

Geliş / Received: 14.01.2021; Kabul / Accepted: 08.03.2021; Online bask1 / Published online: 22.03.2021

Acu, E., Kilıç, V., Kıvanç, M. (2021). Enterococcus durans ile ekstraselüler lipaz üretimi ve karekterizasyonu. GIDA (2021) 46(2) 474-487 doi: 10.15237/gida. GD21020

Acu, E., Kllı, V., Kwvanc, M. (2021). Production and characterization of extracellular lipase from Enterococcus durans. GID A (2021) 46(2) 474-487 doi: 10.15237/gida. GD21020

\section{ÖZ}

Süt ve ürünlerinden izole edilen 50 laktik asit bakterisinin lipaz aktivitesi taranmıştr. E114 ve E114.11 numaralı izolatlarda yüksek aktivite görülmesi nedeniyle enzim üretimi için seçilmiştir. 16S rRNA gen bölgesine göre test bakterilerinin dizi analizi sonuçlanı Enterococcus durans olarak belirlenmiştir. Lipaz üretimi için optimum üretim koşulları belirlenmiştir. Bu koşullar: Azot ve karbon kaynağı olarak $\% 5$ pepton ve $\% 5$ glikoz ile hazırlanan besi ortamının sağlanması, $\mathrm{pH} 6.5^{\prime}$ te 48 saat 120 rpm'de çalkalama ve $40-60^{\circ} \mathrm{C}$ de inkübasyondur. E. durans izolatlarına ait enzimler en yüksek aktiviteyi pH'1 9 olan ve $\% 20$ tuz içeren ortamda göstermiştir. Çeşitli katyonların ve yüzey aktif maddelerin etkisinin farklı olduğu saptanmıştrt. Enzimler düşük ve yüksek sıcaklıklarda aktivite göstermektedir. Ayrıca $5^{\circ} \mathrm{C}$ de 48 saat boyunca enzim aktivitesinin stabil kalması da gida endüstrisi için önem taşımaktadır. Özellikle et ve süt ürünleri gibi fermente ürünlerde lezzet kazandırılması amacıyla kullanılabilirliği umut vericidir.

Anahtar kelimeler: Enterococcus durans, lipaz, enzim aktivitesi

\section{PRODUCTION AND CHARACTERIZATION OF EXTRACELLULAR LIPASE FROM ENTEROCOCCUS DURANS}

\begin{abstract}
Lipase activity of 50 lactic acid bacteria isolated from milk and milk products were screened. E114 and E114.11 isolates were chosen for enzyme production due to their high activity. Sequence analysis results of test bacteria according to $16 \mathrm{~S}$ rRNA gene region were determined as Enterococcus durans. Optimum production conditions for lipase production have been determined. These conditions are: Providing a medium prepared with 5\% peptone and 5\% glucose as nitrogen and carbon source, shaking at $120 \mathrm{rpm}$ for 48 hours at $\mathrm{pH} 6.5$ and incubating at $40-60^{\circ} \mathrm{C}$. Enzymes belonging to $E$. durans isolates showed the highest activity in the environment with pH 9 and containing $20 \%$ salt. It has been found that the effects of various cations and surfactants are different. Enzymes show activity at low and high temperatures. Stability of enzyme activity for 48 hours at $5^{\circ} \mathrm{C}$ is also important for the food industry. Its usability in fermented products such as meat and dairy products is promising.
\end{abstract}

Keywords: Enterococcus durans, lipase, ensyme activity

${ }^{*}$ Yazışmalardan sorumlu yazar / Corresponding author;

$\triangle$ mkivanc@eskisehir.edu.tr

(2) (+90) 5059235003

Esra Acu; ORCID no: 0000-0002-6704-3430

Volkan Kılıç; ORCID no: 0000-0003-3535-8013

Merih KIvanç; ORCID no: 0000-0002-8647-3428 


\section{GİRIŞ}

Enzimler, aktivasyon enerjisini düşürerek reaksiyonu kolaylaştırır ve denge reaksiyonlarının hızlı şekilde gerçekleşmesini sağlarlar. Katalizör olarak bazı kimyasallar da görev yapmaktadır. Ancak asitler ve bazlar gibi kimyasallar, yüksek sermaye yatırımlarına, özel ekipman ve kontrol sistemlerine yol açan yüksek sıcaklık, basınç, asidik veya alkali $\mathrm{pH}$ gerektirmektedirler (Aravindan vd., 2007). Ayrica istenmeyen yan ürünler oluşturabilmektedir. $\mathrm{Bu}$ nedenle araşturicilar kimyasal katalizörlerin yerine kullanılabilecek, spesifik, biyolojik olarak parçalanabilen, geri kazanılması kolay ve yeniden kullanılabilir biyomoleküllere yönelmişlerdir. $\mathrm{Bu}$ biyolojik katalizörler hem hücre dışı hem de hücre içi enzimleri içermektedir (Karigar ve Rao, 2011). Biyolojik lipaz enzimi kimyasallara göre reaksiyonda daha az yan ürün oluşturmaktadır (Treichel vd., 2010). Bu da enzimin biyoteknolojik amaçla özellikle de gıda, ilaç, deterjan, kozmetik, tekstil, kâğıt, enerji ve biyoremediasyon gibi birçok endüstri alanında daha çok tercih edilmesine neden olmaktadır (Treichel vd., 2010; Adrio ve Demain, 2014). Lipaz enzimi, doğada yaygın olarak bulunan bir enzim çeşidi olup trigliseritleri serbest yağ asitlerine ve gliserole hidrolize eden hidrolaz enzim sinifina aittir (Sharma vd., 2011). Ayrıca esterleştirme, transesterifikasyon, hidroliz, asidoliz ve aminoliz gibi farklı reaksiyonları yönetme yeteneğine de sahiptirler (Rajendran vd., 2009).

En çok mikrobiyal lipazların tercih edilme nedeni ise, geniş bir $\mathrm{pH}$ ve sıcaklık aralığında aktif olmaları, geniş substrat spesifikliğinin olması, kolay özütleme ve çok fazla üretim yapabilme kabiliyetleri, kullanım alanlarının fazla olması gibi özelliklerinin bulunmasıdır (Treichel vd., 2010).

Enterococcus spp. lipolitik ve esterolitik aktiviteye sahip olup, uçucu aromatik bileşikleri sentezleme özelliğine sahip olduğu için gidalarda probiyotik ve starter kültür olarak kullanılmaktadır (Giraffa, 2003). Enterococcus spp. peynirlerin olgunlaştırilmasinda (Franz vd., 2003), lipolitik ve proteolitik aktivitesi nedeniyle sucuk aromasının oluşmasına (Hugas vd., 2003) katkıda bulunduğu için geniş çapta kullanılmaktadır. Peynir ve sucuk gibi ürünlerin organoleptik özelliklerini geliştirirler (Franz vd., 2003). Bu özellikleri nedeniyle biyoteknoloji endüstrisinde büyük öneme sahip bakterilerdir.

Bu çalışmada daha önce süt ve ürünlerinden izole edilen Enterococcus sp. izolatlarının lipaz üretim yeteneklerinin taranması, lipaz üretimi için optimum koşulların araştırılması ve enzim aktivitesine etki eden faktörlerin belirlenmesi amaçlanmıştır.

\section{MATERYAL VE YÖNTEM}

Materyal

Çalışmada, daha önceki çalışmalarda çeşitli süt ve ürünlerinden izole edilmiş toplam 50 Enterococcus $s p$. izolatı ile çalışılmıştır. Test bakterileri M17 broth'a ekilerek $37^{\circ} \mathrm{C}^{\prime}$ de 24 saat $\% 10 \quad \mathrm{CO}_{2}$ koşulları altında inkübe edilmiştir. Gelişen kültürler M17 agara ekilerek aynı koşullarda inkübe edilmiş ve oluşan kolonilerin özellikleri incelenerek morfolojik, Gram boyama yapilarak mikroskobik olarak saflıkları kontrol edilmiştir.

Lipaz aktivitesi gösteren izolatlarının seçimi Test bakterileri arasından lipaz aktivitesi gösteren izolatları seçmek için tributrin, zeytinyağ1 ve Tween 80 içeren lipaz besiyerine her bir izolatın 24 saatlik taze kültüründen $50 \mu \mathrm{L}$ ekim yapilmış ve 48 saat $37^{\circ} \mathrm{C}^{\prime} \mathrm{de} \% 10 \mathrm{CO}_{2}$ koşullarında inkübe edilmiştir. İnkübasyon sonunda besiyerinde oluşan şeffaf bölge değerlendirilmiştir (Ko vd., 2005).

\section{Seçilen izolatların tanımlanması}

İzolatların tanımlanmasi $27 \mathrm{~F} \quad 5^{\prime}$ AGAGTTTGATCMTGGCTCAG-3' ve 1492R 5'-TACGGYTACCTTGTTACGACTT-3' evrensel primerleri kullanilarak 16S rRNA gen bölgesine göre dizi analizi yaptırılmışır. Elde edilen dizi bilgileri BioEdit 7.0.5.3 dizi hizalama ve editleme programında düzenlenmiş ve birleştirilmiştir. Daha sonra elde edilen dizi bilgileri National Center for Biotechnology (NCBI) web sitesinde bulunan GenBank veritabanındaki diğer 16S rRNA dizileriyle Blast programı kullanılarak karşılaştırılmış ve izolatlar tür düzeyinde yüzde benzerlik oranıla tanımlanmıştır. 


\section{Seçilen izolatların patojenitesinin belirlenmesi \\ Jelatinaz, hemolitik aktivite ve antibiyotik hassasiyet testleri yapilmıştur. Jelatinaz aktivitesinin belirlenmesi Eaton ve Gasson'a (2001), antibiyotik hassasiyet testi Wayne (2010)'e göre yapılmıştır. Hemolitik aktivite kanlı agarda belirlenmiştir.}

\section{Lipaz üretimi}

Seçilen bakteriler M17 agar da $37^{\circ} \mathrm{C}$ de 48 saat boyunca inkübe edildikten sonra tek koloni olarak M17 broth'a ekilmişlerdir. M17 broth'da gelişen kültürler $37^{\circ} \mathrm{C}^{\prime} \mathrm{de} 24$ saat boyunca inkübe edilmiştir. Kültürler, spektrofotometrede $600 \mathrm{~nm}$ de OD 1 olacak şekilde ayarlanmıştır. Daha sonra $10 \mathrm{~mL}$ olarak tüplere dağıtılan lipaz tayin ortamına (\%3 yeast ekstrakt, \%3 sukroz, $0.1 \mathrm{~g} / \mathrm{C} \mathrm{CaSO}_{4}$, $0.5 \mathrm{~g} / 1 \quad \mathrm{KH}_{2} \mathrm{PO}_{4}, 0.1 \mathrm{~g} / 1 \mathrm{MgSO}_{4} \times 7_{2} \mathrm{O}, \% 1$ tributrin) $\% 1$ oranında kültürlerden ekim yapılmış ve $37^{\circ} \mathrm{C}^{\prime}$ de 48 saat $\% 10 \mathrm{CO}_{2}$ koşullarında inkübe edilmiştir. İnkübasyondan sonra kültürler $4^{\circ} \mathrm{C}$ $9000 \mathrm{rpm}$ de 30 dakika boyunca santrifüj edilmiştir. Oluşan süpernatant pelletten ayrılarak steril falkona aktarılmış ve lipaz aktivitesi belirlenmiştir. Aynı şekilde pellet steril falkonda $20^{\circ} \mathrm{C}$ 'de dondurucuda saklanmış ve daha sonra lipaz aktivitesi belirlenmiştir. Bütün çalışmalar çift paralel olarak yapılmıstur.

\section{Lipaz aktivitesinin belirlenmesi}

Ekstraselüler enzim aktivitesinin belirlenmesi: Lipaz aktivitesi spektrofotometrik olarak belirlenmiştir. p-nitrofenilpalmitat ( $\mathrm{p}-\mathrm{NPP}$ ) substrat olarak kullanılmışır. Lipaz aktivitesini belirlemek için 96 kuyucuklu Eliza petrisine 50 $\mathrm{mM}$ Tris- $\mathrm{HCl}$ içinde hazırlanan $\% 0.4$ tritonX ve $\% 0.1$ gum arabik içeren ( $\mathrm{pH}$ 7) çözeltiden $135 \mu \mathrm{L}$, $10 \mathrm{ml}$ izopropil ile hazırlanan $30 \mathrm{mg}$ p-NPP ile hazırlanan çözeltiden $15 \mu \mathrm{L}$ konulmuştur. Plaklar oda sicaklığında 10 dakika bekletildikten sonra her kuyucuğa hazırlanan süpernatantlardan $50 \mu \mathrm{L}$ ilave edilmiştir. Hazırlanan eliza petrileri $37^{\circ} \mathrm{C}$ 'de \%10 $\mathrm{CO}_{2}$ koşullarında 1 saat bekletildikten sonra renkteki değişim spektrofotometrede $405 \mathrm{~nm}$ 'de okunmuştur (Arora, 2013).

İntrasellüler (peletteki) Enzim Aktivitesi: Süpernatanttan ayrlan pelet $4 \mathrm{ml} 50 \mathrm{mM}$ Tris $\mathrm{HCl}$ tamponda ( $\mathrm{pH}$ 7) süspanse edildikten sonra buz içine yerleştirilmiş ve $30 \mathrm{~W}$ 'da 1dakika sonikasyon uygulanmıştur. Daha sonra $4^{\circ} \mathrm{C} 9000$ rpm'de 30 dakika boyunca santrifüj edilmiştir. Pelet ayrılarak süpernatanttaki intrasellüler enzim aktivitesi belirlenmiştir (Meyers vd., 1996).

Lipaz ünitesi (U) birim zamanda (dakika) $1 \mu \mathrm{mol}$ p-Nitrofenol açığa çıkaran enzim miktarı olarak belirlenmiştir. Hesaplamalar standard pNitrofenol eğrisi kullanılarak yapılmıştır

\section{Çevresel Faktörlerin Enzim Üretimine Etkisinin Belirlenmesi \\ Sucakliğn etkisi}

Kat1 besiyerinde; Lipaz kat1 besiyerine $5 \mu \mathrm{L}$ kültürlerden ekim yapılmıştır. Plaklar $4^{\circ} \mathrm{C}, 20^{\circ} \mathrm{C}$, $25^{\circ} \mathrm{C}, 30^{\circ} \mathrm{C}, 35^{\circ} \mathrm{C}, 40^{\circ} \mathrm{C}, 45^{\circ} \mathrm{C}, 50^{\circ} \mathrm{C}$ sicakliklarda 48 saat inkübe edilerek bakterilerin gelişme durumu incelenmiştir.

Sivı besiyerinde; Test bakterileri $37^{\circ} \mathrm{C}$ 'de 24 saat $\% 10 \mathrm{CO}_{2}$ koșullarında inkübe edildikten sonra 600 nm'de OD.1'e ayarlanıp deney tüplerinde bulunan 10 mL'lik lipaz tayin ortamina 2 paralel ekim yapilmıştır. Deney tüpleri $4^{\circ} \mathrm{C}, 20^{\circ} \mathrm{C}, 30^{\circ} \mathrm{C}$, $40^{\circ} \mathrm{C}, 50^{\circ} \mathrm{C}, 60^{\circ} \mathrm{C}$ sicakliklarda 48 saat inkübe edilerek lipaz aktivitesine sicaklığın etkisi araştırllmıştır (Bharathi vd., 2018).

Substrat sıcaklığının etkisini belirlemek için, 96 kuyucuklu Eliza petrisine $50 \mathrm{mM}$ Tris- $\mathrm{HCl}$ içinde hazırlanan $\% 0.4$ tritonX-100 ve $\% 0.1$ gum arabik içeren (pH 7) çözeltiden $135 \mu \mathrm{l}, 10 \mathrm{~mL}$ izopropil ile $30 \mathrm{mg}$ p-NPP ile hazırlanan çözeltiden $15 \mu \mathrm{L}$ konulmuştur. Hazırlanan Eliza petrileri $4^{\circ} \mathrm{C}$, $25^{\circ} \mathrm{C}, 30^{\circ} \mathrm{C}, 35^{\circ} \mathrm{C}, 40^{\circ} \mathrm{C}, 45^{\circ} \mathrm{C}, 50^{\circ} \mathrm{C}$ sicakliklarda $10 \mathrm{dk}$ bekletildikten sonra her kuyucuğa hazırlanan süpernatantlardan $50 \mu \mathrm{L}$ ilave edilmiş ve belirlenen sicakliklarda 1 saat bekletilmiştir. Daha sonra spektrofotometrede $405 \mathrm{~nm}$ 'de değerlendirilmiştir. Bütün okumalar 4 paralel olacak şekilde yapılmıştır.

\section{Karbon ve azot kaynaklarmm etkisi}

Lipaz aktivite tayin ortamına karbon kaynağ1 olarak, sukroz yerine $\% 3$ glikoz ve $\% 3$ laktoz kullanılmıştır. Üretilen lipaz enziminin aktivitesi belirlenerek en etkili karbon kaynağ1 belirlenmiştir. 
Lipaz aktivite tayin ortamına azot kaynağ olarak $\% 2$ ve $\% 5$ oranlarında pepton, amonyum sülfat ve yeast ekstrakt kullanılarak üretilen enzimin aktivitesine etkisi belirlenmiştir.

\section{pH'nnn etkisi}

Lipaz aktivitesine pH'ın etkisini belirlemek için lipaz tayin ortaminin $\mathrm{pH}^{\prime} 1$ 5.5, 6.5, 7.5'e ayarlanmıștır. Test bakterileri farklı pH'lardaki lipaz tayin ortamında geliştirilerek elde edilen enzimin aktivitesi belirlenmiştir.

\section{Calkalamann ve inkë̈basyon süresinin etkisi}

Lipaz aktivitesine çalkalamanın etkisini belirlemek için test bakterileri statik ve $120 \mathrm{rpm}$ çalkalamalı etüvde geliştirilerek elde edilen enzimin aktivitesi belirlenmiştir.

Lipaz aktivitesine inkübasyon süresinin etkisini belirlemek için test bakterileri 24, 48 ve 72 saat inkübe edilmiştir. İnkübasyon süresi sonunda elde edilen enzimin aktivitesi belirlenmiştir.

\section{Enzim üretimi}

En yüksek enzim aktivitesinin elde edildiği koşullarda enzim üretimi gerçekleştirilmiştir. Yapılan çalışmalarda elde edilen sonuçlar dikkate alınarak enzim üretimi için $500 \mathrm{~mL}$ 'lik lipaz tayin ortamı hazırlanmıştur. Lipaz tayin ortamında azot kaynağı olarak $\% 5$ pepton, karbon kaynağı olarak $\% 3$ glikoz konulmuş ve diğer bileşenler sabit kalmıştır. Lipaz ortamının $\mathrm{pH}^{\prime} 1$ ise 6.5-7 olarak ayarlanmıştır. \%10 $\mathrm{CO}_{2}$ koşullarında $37^{\circ} \mathrm{C}^{\prime}$ lik çalkalamalı etüvde 48 saat boyunca inkübe edilmiştir. İnkübasyon sonrasinda $9000 \mathrm{rpm}$ $4^{\circ} \mathrm{C}$ 'de $30 \mathrm{dk}$ santrifüj yapılmıştr. Elde edilen filtrata soğutulmuş aseton 1:5 oranında olacak şekilde karıştırılarak 24 saat $4^{\circ} \mathrm{C}$ de bekletilmiş ve $9000 \mathrm{rpm}, 4^{\circ} \mathrm{C}$ 'de $15 \mathrm{dk}$ santrifüj yapılmıştır.

Daha sonra diyaliz tüpüne (Sigma PURX12015) enzimden $3 \mathrm{~mL}$ konulmuştur. Tris $\mathrm{HCl}$ tamponu içine diyaliz tüpü yerleştirilmiştir. 24 saatte bir Tris $\mathrm{HCl}$ tamponu değiştirilmiştir. 48 saat sonunda ise kısmi olarak saflaşan enzim deneylerde kullanılmıştır.

\section{Lipazın molekül ağırlığının belirlenmesi}

Lipaz enziminin protein miktar1 Bradford yöntemi ile belirlenmiştir (Bradford, 1976).
Coomassie Brillant Blue G-250 boyas1 kullanılarak 590 nm'de spektrofotometrede okuma yapılarak değerlendirilmiştir.

Enzimin molekül ağırllğ1 Laemmli (1970) yöntemine göre SDS-PAGE (sodyum dodesil sülfat-poliakrilamid jel elektroforezi) ile belirlenmiştir.

Kısmi saflaştırılmış ekstraselüler enzim aktivitesine etki eden faktörlerin belirlenmesi Kısmi olarak saflaşturlan lipaz enzimlerinin aktivitesi üzerine sıcaklığın, $\mathrm{pH}$ 'ın, çeşitli katyon, yüzey aktif madde ve çözeltilerin etkisi belirlenmiştir.

\section{Sıcaklığın enzim aktivitesine etkisi}

Sicaklığı lipaz enzim aktivitesi üzerine etkisini belirlemek için enzim $50 \mathrm{mM}$ sodyum fosfat tampon (pH 7) içinde $5^{\circ} \mathrm{C}, 20^{\circ} \mathrm{C}, 30^{\circ} \mathrm{C}, 37^{\circ} \mathrm{C}, 40$ ${ }^{\circ} \mathrm{C}, 45^{\circ} \mathrm{C}, 55^{\circ} \mathrm{C}$ ve $65^{\circ} \mathrm{C}$ 'de 1 saat inkübe edildikten sonra enzim aktivitesi belirlenmiștir.

Sıcaklık stabilitesi belirlemek için lipaz $50 \mathrm{mM}$ sodyum fosfat tampon ( $\mathrm{pH} 7$ ) içinde konularak $5^{\circ} \mathrm{C}, 20^{\circ} \mathrm{C}, 30^{\circ} \mathrm{C}, 45^{\circ} \mathrm{C}$ ve $55^{\circ} \mathrm{C}$ de $5 \mathrm{dk}, 1 \mathrm{~s}, 4 \mathrm{~s}, 24$ $\mathrm{s}$ ve $48 \mathrm{~s}$ süre ile inkübe edildikten sonra aktivite belirlenmiştir (Esteban-Torres vd., 2015).

\section{pH'ın enzim aktivitesi üzerine etkisi}

pH 3-11 arasinda hazırlanan tamponlarda enzim bekletilerek pH'ın lipaz aktivitesi üzerine etkisi belirlenmiştir. $\mathrm{pH}$ 3-5 için asetik asit-sodyum asetat tampon, $\mathrm{pH} 6$ için sodyum fosfat tampon, $\mathrm{pH}$ 7-8 için Tris- $\mathrm{HCl}$ tampon, $\mathrm{pH} 9$ için glisin$\mathrm{NaOH}$ tampon kullanılmıştr.

Enzimin pH direncini belirlemek için ependorflara farklı pH'lardaki tamponlardan 200 $\mu \mathrm{L}$ konulmuştur. Üzerine ise $200 \mu \mathrm{L}$ enzim ilave edilerek $45^{\circ} \mathrm{C}$ 'de 2 ve 3.5 saat inkübe edilmiştir. Kalan enzim aktivitesi belirlenmiştir.

Bazı çözeltilerin ve katyonların enzim aktivitesine etkisi

Bazı katyon, sürfektan ve çözeltilerin enzim aktivitesi üzerine etkisini belirlemek için $\mathrm{MnCl}_{2}$, $\mathrm{CuCl}_{2}, \mathrm{MgCl}_{2}, \mathrm{KCl}, \mathrm{NiCl}_{2}, \mathrm{CaCl}_{2}, \mathrm{HgCl}_{2}, \mathrm{ZnCl}_{2}$ 'ün son konsantrasyonu $1 \mathrm{mM}$ olacak şekilde ilave 
edilmiş ve enzim aktivitesi 405 nm'de spektrofotometrede belirlenmiştir. Üre, EDTA, SDS, tween 20, tween 80, tritonX-100'ün enzim aktivitesine etkisi ortama $1 \mu \mathrm{L}$ ilave edilerek belirlenmiştir.

\section{Tuzun enzim aktivitesine etkisi}

Sodyum klorürün $(\mathrm{NaCl})$ etkisini belirlemek için $\% 0, \% 1, \% 5, \% 10, \% 15, \% 20, \% 25$ (w/v) konsantrasyonlarında $\mathrm{NaCl}$ tampona ilave edilmiştir. Enzim aktivitesi 405 nm'de spektrofotometrede belirlenmiştir (EstebanTorres vd., 2015).

\section{SONUÇLAR VE TARTIŞMA}

\section{Seçilen İzolatların Tanımlanması}

Lipaz üretimi, açısından taranan 50 izolattan E114 ve E114.11 numaralı izolatlarda elde edilen şeffaf bölge çaplanı daha yüksek olduğu için lipaz üretiminde bu izolatlar kullanılmak üzere seçilmiştir. 16S rRNA gen bölgesine göre dizi analizi sonuçları ile test bakterileri E. durans olarak belirlenmiştir (Çizelge 1).

Çizelge 1. Test bakterilerinin 16S rRNA gen bölgesine göre tanımlanması Table 1. Identification of test bacteria according to $16 \mathrm{~S} r \mathrm{RN} A$ gene region

\begin{tabular}{llcc}
\hline Kod no & Tanimlama & Benzerlik $(\%)$ & Erişim no \\
Code no & Identification & Similarity $(\%)$ & Accession no \\
\hline E114 & Enterococcus durans & 99.58 & MF582823.1 \\
E114.11 & Enterococcus durans & 99.29 & MF582969.1 \\
\hline
\end{tabular}

Ampisiline, gentamisine ciprofloksasin ve vankomisine her iki $E$. durans izolatı da dirençli olarak bulunmuştur. Jelatinaz aktivitesi ve hemoliz aktivitesi her iki E. durans izolatı için de negatif olarak saptanmıştır. Laktik asit bakterileri vankomisine doğal olarak dirençli olduğu, vankomisin direncinin hücre duvarının sentezi sırasında D-alanin ve D laktada vankomisin bağlanamadığ1 ile ilişkili olduğu düşünülmektedir (Handwerger vd., 1994). Süt ve süt ürünlerinde izole edilen enterokokların gentamisine dirençli oldukları rapor edilmiştir (Çitak vd., 2004).

\section{Lipaz Enzimi Üretimi}

Test bakterilerinin lipaz üretimleri Tween 20, Tween 80, tributrin, zeytinyağ1 ortamında test edilmiştir. İzolatların 11 tanesinin tributrin içeren ortamda lipaz ürettikleri saptanmıştır. Tween 80 ve zeytinyağında lipaz üretimi saptanamamıştır. Tanasupawat vd., (2015) Lactobacillus pentosus ve Pediococcus lolilin Tween 80 içeren ortamda yüksek miktarda lipaz ürettiğini bildirmişlerdir. Ramyasree ve Dutta, (2013) Lactobacillus lactis, Lactobacillus brevis ve Lactobacillus plantarum'un substrat olarak limon yağı, zeytinyağını ve gül yağını kullanabildiğini bildirmiştir. Tributrin gerçek yağ olup doğal yağlarda meydana gelen en basit trigliserittir. Tributrin suda kolay dispers olduğu için bu tip çalışmalarda daha çok tercih edilmektedir (Samad vd., 1989). Bu çalışmada da test ettiğimiz izolatların hiçbiri zeytinyağını hidrolize edememiştir. Sadece tributrinde aktivite göstermişlerdir. Ancak, Lopes vd., (2002) tributrinin spesifik olmadığını lipazlar ve esterazların ikisini de ayırdığını bildirmişlerdir. Bu nedenle tributrinin ilk aşamada kullanılmasının daha uygun olacağını rapor etmişlerdir.

Javed vd., (2018) bakteri lipazlarının genellikle hücre dışı olarak üretilmelerine karşın hücre içi veya membrana bağlı da olabildiklerini bildirmişlerdir. Önceki çalışmalarda da (Piatkiewicz, 1987; Meyer vd., 1996) laktik asit bakterilerinin intrasellüler lipazları da gösterilmiştir. Çalışmamızda ekstraselüler lipaz aktivitesi daha yüksek olarak saptandığı için çalışmalara ekstraselüler lipaz ile devam edilmiştir.

\section{Lipaz Enzimi Üretimine Etki Eden Çevresel Faktörler \\ Sicakliğın etkisi}

E. durans 114 ve E. durans $114.11,20-50^{\circ} \mathrm{C}$ de benzer şekilde gelişmiştir. $40-60^{\circ} \mathrm{C}$ de gelişen kültürlerden elde edilen enzimlerin aktivitesi daha yüksek olmuştur (Şekil 1). Bakterilerin metabolik aktiviteleri düşük sıcaklıkta yavaşlamaktadır 
(Amato ve Christner, 2009; Uppada ve Dutta, 2012).
Subsrat sıcaklı̆̆1 lipaz aktivitesini etkilemiştir. Substrat sicakliğ1 $45^{\circ} \mathrm{C}$ olduğunda en yüksek enzim aktivitesi gerçekleşmiştir.

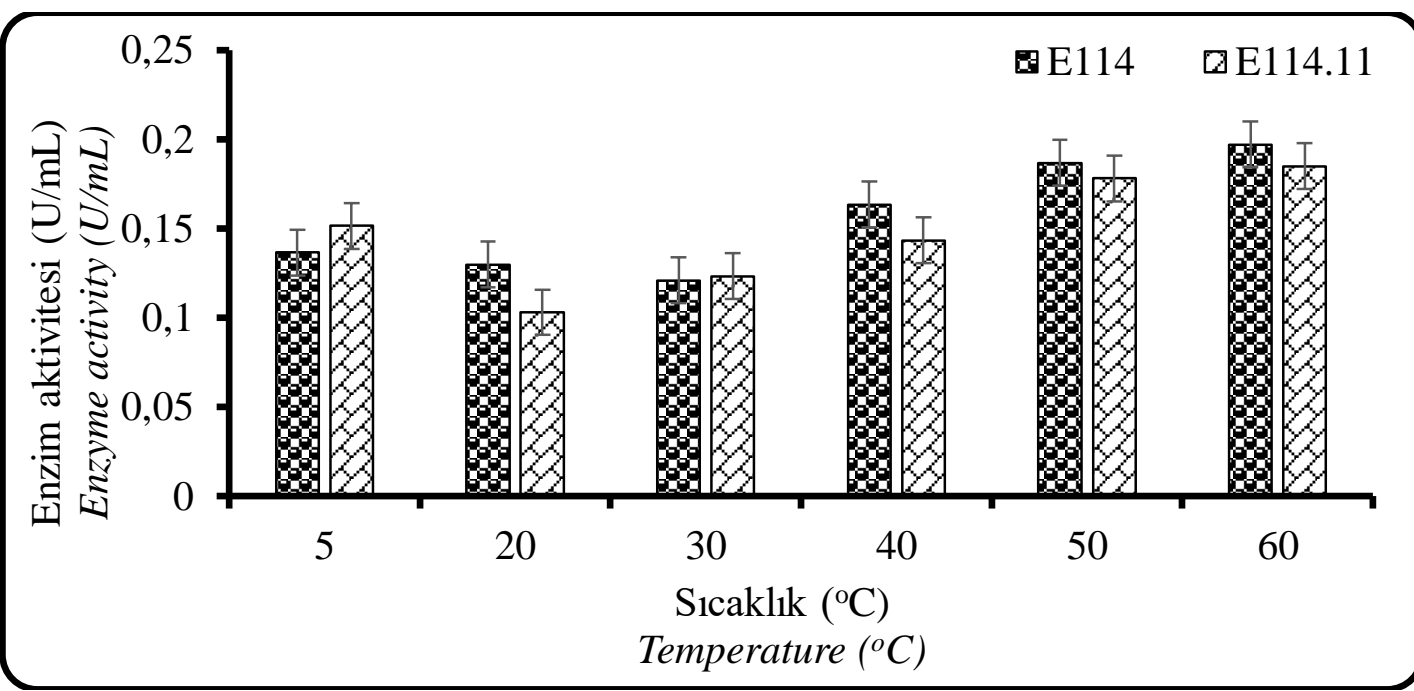

Şekil 1. Farklı sıcaklıklarda geliştirilen E. durans E114 ve E114.11‘e ait ekstraselüler lipaz enziminin aktivitesi

Figure 1. Activity of extracellular lipase ensyme of E. durans E114 and E114.11 that were developed at different temperatures

\section{Calkalama ve fermantasyon süresinin etkisi}

E. durans E114 ve E114.11 için optimum fermantasyon süresi 48 saat olarak saptanmıştır. En yüksek enzim aktivitesi 48 saat inkübe edilen örneklerde elde edilmiştir. Ramyasree ve Dutta, (2013) L. lactis, L. brevis ve L. plantarum için optimum inkübasyon süresini bulgularımızdaki gibi 48 saat olarak bildirmiştir. Lipaz aktivitesi fermantasyon süresine bağlı olarak artmıştır. Ancak aktivite belirli bir fermantasyon süresinden sonra düşmüsstür. Aktivitedeki azalmanın nedeni ortamdaki besin maddelerinin azalması olabileceği gibi ortamda bakteriyel toksinlerin birikmesi de olabilir.

Çalkalamalı (120 rpm) olarak üretilen bakterilerden elde edilen enzimin aktivitesi statik olarak üretilenlerdeki enzimin aktivitesinden yüksek olmuştur.

\section{Arot ve karbon kaynaklarmm etkisi}

Farklı azot kaynaklarında geliştirilen test bakterilerinden elde edilen lipaz enziminin aktivitesi değişmiştir. En etkili azot kaynağ1 \%5 pepton olarak saptanmıştır (Şekil 2). Yeast ekstraktın ve amonyum sülfatın fazla bir etkisi olmamıştır.

Karbon kaynağı olarak besiyerine $\% 3$ oranında laktoz, glikoz ve sukroz ilave edilmiştir. Bu karbon kaynaklarında üretilen bakterilere ait enzimlerin aktivitelerine bakıldığında en yüksek aktivite glikoz kullanıldığına elde edilmiştir (Şekil 2).

Laktik asit bakterileri ile lipaz enzimi üretiminde karbon kaynağı olarak glikoz azot kaynağ1 olarak pepton kullanıldığında en yüksek aktivite elde edildiği birçok araştırıcı tarafindan vurgulanmıştır (Bhargavi vd., 2010). Araştırıcıların bu durumun tek karbon kaynağı ve lipid indüserin bulunması durumunda elde edildiğini bildirmişlerdir. Petrovic vd., (1990) de ekstraselüler lipaz üretimi için en uygun karbon kaynağını bizim bulgularımıza benzer olarak glikoz, Sangeetha vd., (2008) azot kaynağını pepton olarak saptamışlardır. 


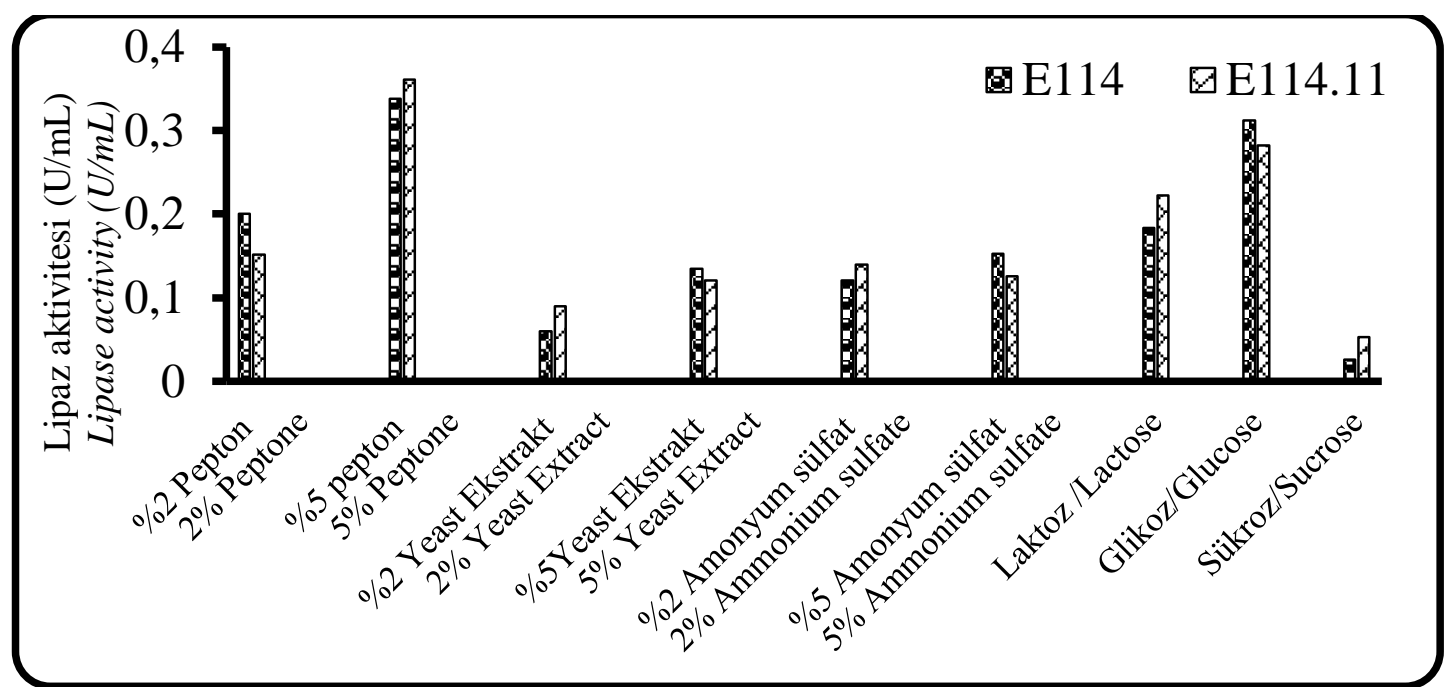

Şekil 2. Farklı azot ve karbon kaynaklarında geliştirilen E. durans 114 ve 114.11'e ait ekstraselüler lipaz enzimlerinin aktivitesi.

Figure 2. Activity of extracellular lipase ensymes belonging to E. durans 114 and 114.11 that were developed in different nitrogen and carbon sources.

\section{pH'inm etkisi}

Farklı pH (5.5, 6.5 ve 7.5) larda geliştirilen E. durans izolatlarına ait lipaz enziminin aktivitesi en yüksek pH 6.5 da gelişen E. durans izolatlanında olmuştur. Optimum $\mathrm{pH}$ dan çok yüksek ve çok düşük $\mathrm{pH}$ üretimi önemli ölçüde etkilemektedir (Kumar ve Kanwar, 2012).

\section{Lipaz Enziminin Moleküler Ağırlığı}

E. durans izolatları için $120 \mathrm{rpm}$ çalkalama hızında 48 saat inkübasyon süresi optimum olarak belirlenmiştir. Optimum sicaklık $45^{\circ} \mathrm{C}, \mathrm{pH}$ 6.5, azot kaynağı olarak $\% 5$ pepton, karbon kaynağ glikoz olarak saptanmışur. Yapılan benzer çalışmalarda bakterilere göre değişen koşullar saptanmıştur. Bu koşullarda üretilen E. durans izolatlarıdan elde edilen kısmi saflaştırılmış ekstraselüler lipaz enzimlerinin kuru ağırlık ve protein miktarları Çizelge 2' de verilmiştir.

Çizelge 2. E. durans ait ekstraselüler lipaz enzimlerinin kuru ağırlık ve protein miktarları Table 2. Dry weight and protein amounts of extracellular lipase ensymes of E. durans

\begin{tabular}{lccc}
\hline $\begin{array}{l}\text { Bakterilerin kodlar1 } \\
\text { Bacterial codes }\end{array}$ & $\begin{array}{c}\text { Protein miktar1 } \\
\text { (BSA mg/mL) } \\
\text { Protein content } \\
\text { (BSA mg/ mL) }\end{array}$ & $\begin{array}{c}\text { Kuru ağırlık }(\mathrm{mg} / \mathrm{mL}) \\
\text { Dry weight }(\mathrm{mg} / \mathrm{mL})\end{array}$ & $\begin{array}{c}\text { Yaş ağırlik }(\mathrm{mg} / \mathrm{mL}) \\
\text { Wet weight }(\mathrm{mg} / \mathrm{mL})\end{array}$ \\
\hline E114 & 0.247 & 0.300 & 0.477 \\
E114.1 1 & 0.275 & 0.444 & 1.040 \\
\hline
\end{tabular}

Kısmi saflaşturılan enzimin moleküler ağırlı̆̆1 yaklaşık olarak $23 \mathrm{kDa}$ olarak bulunmuştur (Şekil 3). Ramakrishnan vd., (2012) Enterokok lipaz enziminin moleküler ağırllı̆ını $22.86 \mathrm{kDa}$ olarak bildirmişlerdir. Ramakrishnan vd., (2016) E. faecium'a ait saflaştırılmış enzimin moleküler ağırlı̆̆ını $19.2 \mathrm{kDa}$ olarak bulmuş̧lardır.
Kısmi saflaştırılmış ekstraselüler enzim aktivitesine etki eden faktörlerin belirlenmesi Kısmi saflaşturlmış ekstraselüler enzim aktivitesine etki eden sıcaklık, $\mathrm{pH}$, çeşitli katyon ve sürfektanların etkisi belirlenmiştir. 


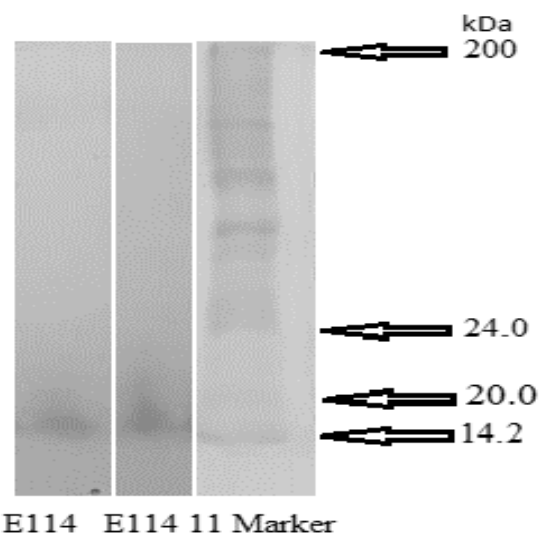

Şekil 3. SDS-PAGE ile kısmen saflaştırılmış E. durans' $a$ ait lipazın moleküler ağırllı̆g

Figure 3. Molecular weight of partially purified lipase of E. durans by SDS-PAGE

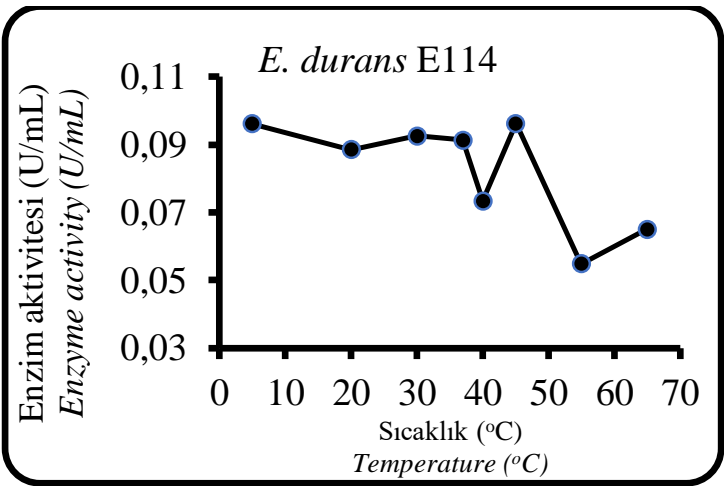

Enzim aktivitesi üzerine sıcaklığın etkisinin belirlenmesi

Kısmi saflaştrilmış ekstraselüler enzim aktivitesine sıcaklı̆̆ın etkisi bakterilere göre değişmiştir. E. durans E114 dan elde edilen kısmi saflaştırilmış ekstraselüler enzim $30-45^{\circ} \mathrm{C}$ de maksimum aktivite gösterirken E. durans E114.11'e ait ekstraselüler enzimlerin aktivitesi $30^{\circ} \mathrm{C}$ den daha yüksek sicaklıklarda azalmıștır (S.ekil 4). Enterococcus faecium'da maksimum aktivitenin $40^{\circ} \mathrm{C}$ 'de gerçekleştiği bildirilmiştir (Ramakrishnan vd., 2016).

Şekil 4. E. durans izolatlarına ait kısmi saflaştırılmış ekstraselüler lipaz enziminin aktivitesi üzerine sicaklığın etkisi.

Figure 4. Effect of temperature on the activity of the partially purified extracellular lipase ensyme of E. durans isolates.
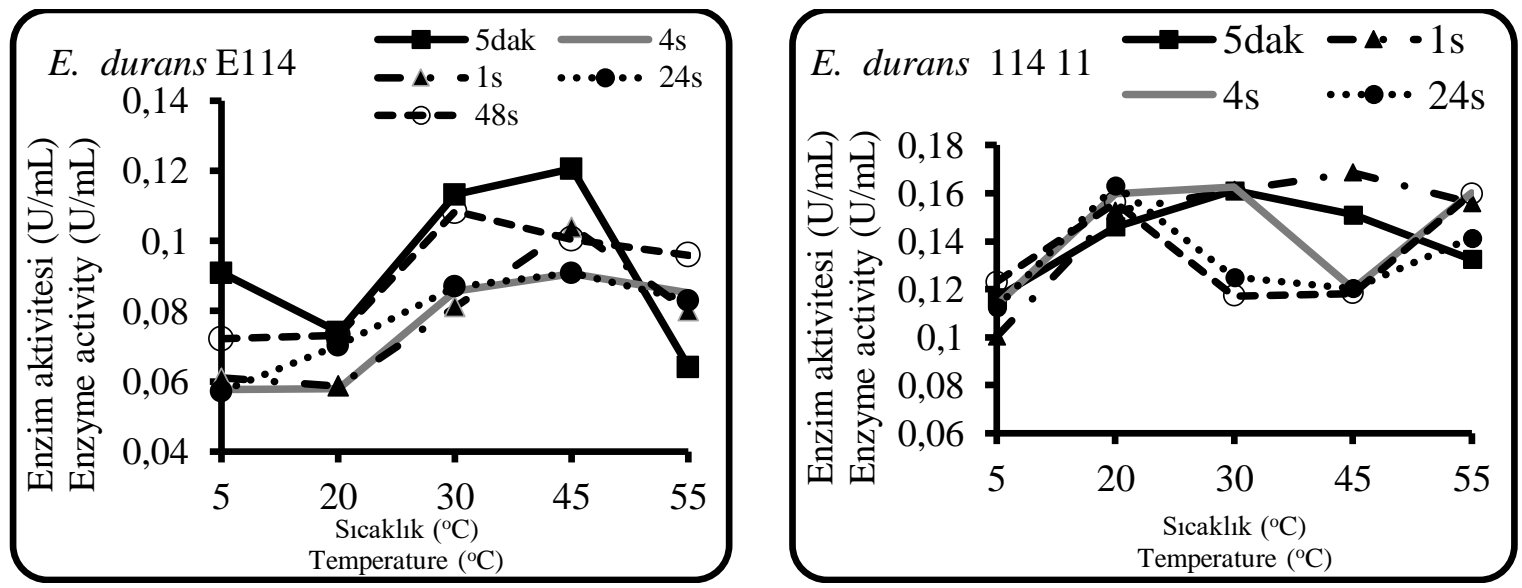

Sekil 5. E. durans izolatlarına ait kısmi saflaștırılmıș ekstraselüler lipaz enziminin farklı sıcaklıklarda farklı bekleme sürelerine göre sıcaklık direnci.

Figure 5. Temperature resistance of the partially purified extracellular lipase ensyme of E. durans isolates at different temperatures according to different time periods 
Farklı sicakliklarda 5 dak, 1s, 4s, 24 ve 48s bekletilen ekstraselüler lipaz enzimlerinin sicaklık direnci farklı olmuştur (Şekil 5). E. durans 114.11'a ait kısmi saflaştırılmış lipaz enziminin aktivitesi $55^{\circ} \mathrm{C}$ de stabil kalırken $E$. durans 114 'e ait ekstraselüler enzimin aktivitesi düşmüştür. $E$. durans 114'e ait ekstraselüler enzimin aktivitesi sicaklıklara bağlı olarak bekleme süresince değişen oranlarda aktivite kaybi olurken E. durans 114.11'a ait kısmi saflaştırılmış lipaz enziminin aktivitesi $20^{\circ} \mathrm{C}$ de stabil kalmıştır (Şekil 5). Ramakrishnan vd., (2016) E. faecium'a ait lipaz enzimi aktivitesinin en yüksek $40^{\circ} \mathrm{C}$ de olduğunu aktivitenin $30-70^{\circ} \mathrm{C}$ de stabil olduğunu rapor etmişlerdir. Araşturıcılar enzim aktivitesinin 80$100^{\circ} \mathrm{C}$ de stabil olduğunu $100^{\circ} \mathrm{C}$ den sonra enzim aktivitesinin kalmadığını bildirmişlerdir. EstebanTorres vd., (2015) L. plantarum'a ait esteraz enziminin maksimum aktivitesinin $40^{\circ} \mathrm{C}$ de olduğunu, $5^{\circ} \mathrm{C}$ de enzimin aktivitesinin ancak $\% 40$ 'nn gösterdiğini, $55^{\circ} \mathrm{C}$ ve $65^{\circ} \mathrm{C}$ de 10 saat inkübasyondan sonra ise aktivitenin \%40'inın kaldığını bildirmişlerdir. Sıcaklık, enzimin şeklini değiştirerek ve moleküler hareket hızını değiştirerek enzim aktivitesini etkileyebilmektedir (Enger, 2012). Çalışmada, E. durans 114.11'e ait enzimin $5^{\circ} \mathrm{C}$ de 48 saat süresince aktivitesi stabil kalmıştır. Bu durum gıda endüstrisinde önem taşımaktadır. Gıdaların et ve süt ürünlerinin olgunlaşma sırasında uzun süre düşük sicaklıkta tutulduğu göz önüne alındığında arzu edilen aromanın oluşmasında bu enzim rol oynayabilir. Peynir gibi gidaların depolama sicakliklarında lipaz aktivitesi önem taşımaktadır. Çalışmamızda depolama süremiz 48 saat ile sinırlı kalmıştır. Lipaz enziminin sıcaklık stabilitesi gida endüstrisinde önem taşımaktadır (Choo vd., 1998). Enzimler $55^{\circ} \mathrm{C}$ de 24 ve 48 saat inkübasyonda stabilitesini korumuştur. Yüksek sicaklikta $\left(70^{\circ} \mathrm{C}\right)$ aktif bölgeler, substrata uyamayacak şekilde değişir ve bu sıcaklıkta enzim denatüre olur ve sonuçta enzim aktivitesi büyük ölçüde azalmaktadır (Toole ve Toole, 2004).

\section{Enzim aktivitesi üzerine pH'ın etkisi}

Farklı tamponlar kullanılarak hazırlanan E.durans ait ekstraselüler lipaz enzim aktiviteleri asidik ve nötr $\mathrm{pH}$ da düşükken $\mathrm{pH}$ alkaliye doğru çıkıldıkça enzimlerin aktivitelerinde artış saptanmıştır. E. durans, izolatlarına ait enzim $\mathrm{pH} 9$ da en yüksek aktiviteyi göstermiştir (Şekil 6). Dellali vd., (2020) E. durans ve E. faecium ait lipaz için optimum $\mathrm{pH}$ 'y1 6-9 arasında saptadıklarını bildirmişlerdir.
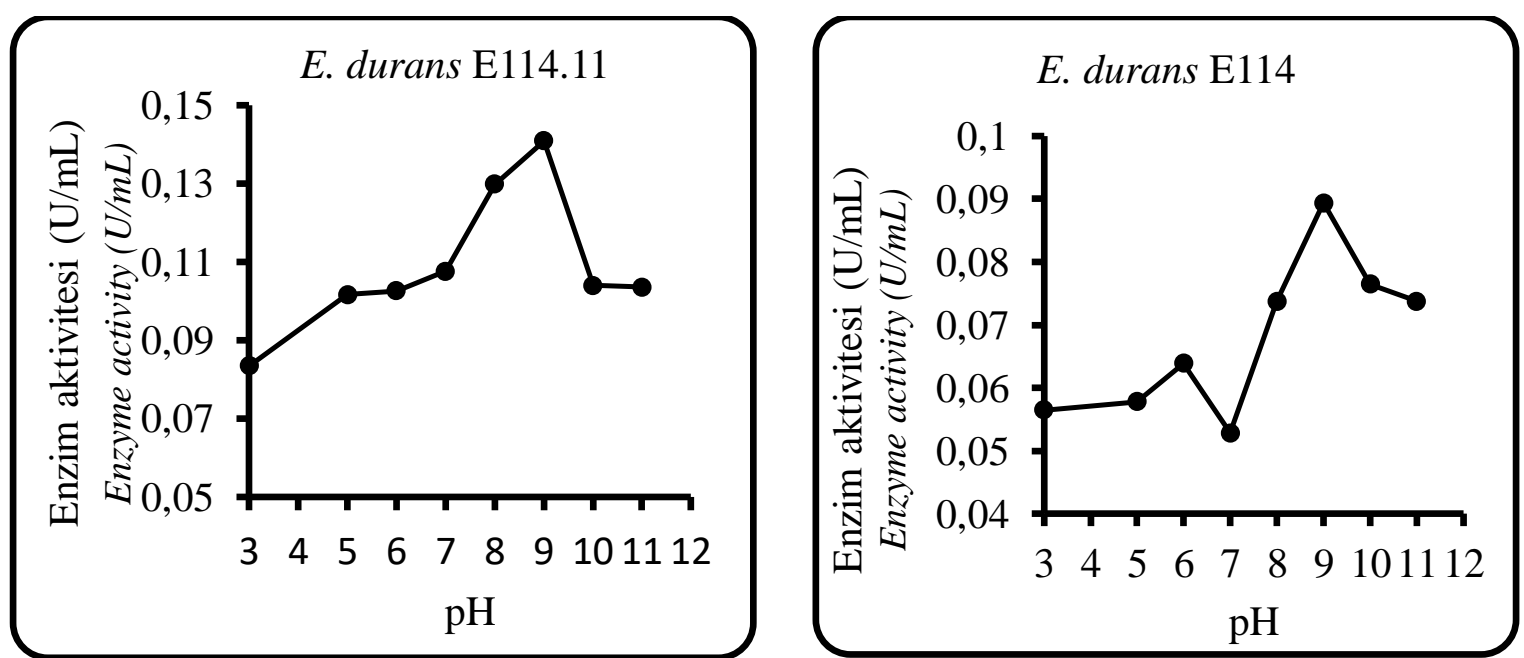

Şekil 6. Kısmi saflaştırılmış ekstraselüler lipaz enziminin aktivitesi üzerine $\mathrm{pH}$ 'ın etkisi Figure 6. Effect of $p H$ on the activity of the partially purified extracellular lipase ensyme 


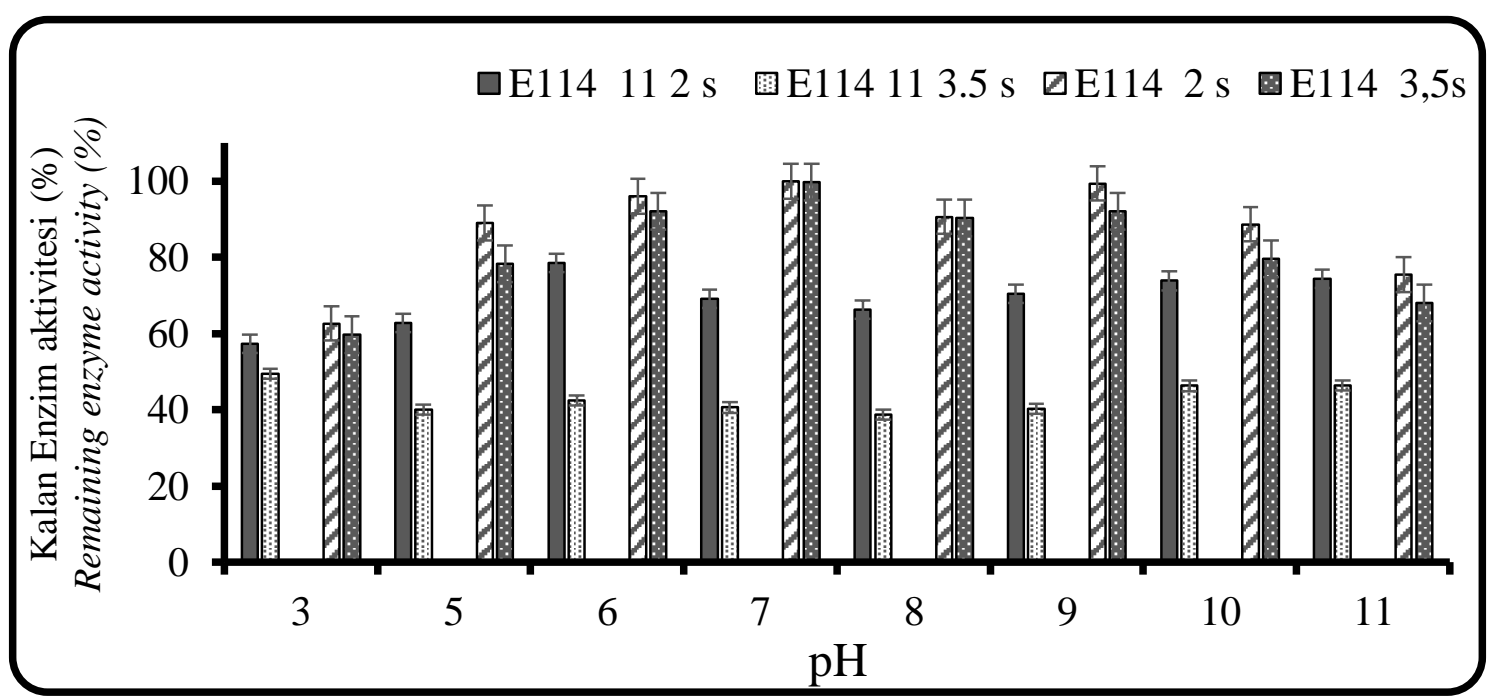

Şekil 7. Kısmi saflaşturilmış ekstraselüler lipaz enzimi aktivitesinin $\mathrm{pH}$ direnci Figure 7. pH resistance of partially purified extracellular lipase ensyme activity

Farklı pH'larda 2 ve 3.5 saat bekleme süresinde E114'e ait enzimde önemli aktivite kayb1 gözlenirken E. durans E114.11 ait enzimin aktivite kaybı daha düşük olmuştur. Aktivite kaybı genellikle 3.5 saat bekleme süresinde daha fazla olmuştur (Şekil 7). Ramakrishnan vd., (2016) E. faecium lipazı için optimum pH'1 10.8 olarak bildirmişlerdir. $\mathrm{pH}$ 7-12 arasinda iken enzim aktivitesinin stabil kaldığını asidik $\mathrm{pH}$ da ise aktivite kayb1 olduğunu rapor etmişlerdir. Çalısmada optimum $\mathrm{pH}$ değerlerinden sonra aktivitede azalma görülmüştür. Araştırıcılar asidik koşullarda lipaz aktivitesindeki düşüklüğün $\mathrm{Ca}^{+2}$ iyonlanının kaybı ile enzimin aktif bölgesindeki koordinasyon ile ilişkili olabileceğini bildirmişlerdir. Esteban-Torres vd., (2015) de L. plantarum'dan elde edilen esteraz enzimi için optimum pH 7 olarak bildirmişlerdir. Genel olarak, bakteriler tarafindan üretilen lipazlar nötr veya alkalin $\mathrm{pH}$ optimuma sahiptir. $\mathrm{pH}$ 'daki herhangi bir değişiklik, enzimler üzerindeki elektrik yüklerinin değişmesine neden olabileceğinden enzimin üçüncül ve kuaterner yapılarını stabilize eden iyonik bağları etkileyebilmektedir. Bu durum ise enzimin üç boyutlu yapısında ve aktivitesinde değişmeye neden olarak enzim aktivitesinin düşmesine neden olmaktadır (Sukohidayat vd., 2018).
Enzim aktivitesi üzerine katyon, deterjan ve yüzey aktif maddelerin etkisi

Yüzde 1 olarak ilave edilen $\mathrm{HgCl}_{2}, \mathrm{CaCl}_{2}, \mathrm{MnCl}_{2}$, $\mathrm{NiCl}_{2}, \mathrm{KCl}, \mathrm{ZnCl}_{2}, \mathrm{MgCl}_{2}$ gibi katyonlarnn E114 ve E114.11 'den elde edilen enzimlerin aktivitesi üzerine etkisi farklı olmuştur (Çizelge 3). EDTA ve üre gibi maddeler de E. durans 114.11'e ait enzimde aktiviteyi artırırken E. durans 114'ten elde edilen enzimin aktivitesi üzerine etkili olmamıştır. Ramakrishnan vd., (2016) E. faecium MTCC5695'in optimum koşullarda üretilen enzimin aktivitesini EDTA'nın inhibe ettiğini bildirmișlerdir. $\mathrm{HgCl}_{2}$ ve SDS her iki ekstraselüler enziminde aktivitesinde azalmaya neden olmuştur. SDS enzimin aktif bölgesinde konformasyonel değişikliğe sebep olarak enzim yüzeyinin hidrofobikliği üzerinde değişikliklere yol açabilir. Sonuçta enzimin üçüncül yapısı bozularak enzimin inaktive olmasina neden olabilir (de Almeida vd., 2013).

$\mathrm{Ca}^{+2}, \mathrm{Mg}^{+2}$ ve $\mathrm{Mn}^{+2}$ iyonlar1, E. durans E114.11'den elde edilen ekstraselüler lipaz enziminin aktivitesini artırırken E. durans E114 den elde edilen ekstraselüler enzim aktivitesi üzerine etkili olmamıştır. Lopes vd., (2002) laktik asit bakterilerine ait lipaz enziminin aktivitesi üzerine $\mathrm{Ca}^{+2}$ ' 1 etkili olmadığını rapor etmişlerdir. $\mathrm{Ca}^{+2}$ ve $\mathrm{NaCl}$ yağ asidi akseptörü olarak ya da ara yüzey yükünü baskilama etkisi nedeniyle ortama 
ilave edilmektedir. Ayrica $\mathrm{Ca}^{+2}$ iyonlarının varlığında lipaz enziminin aktivite artışına neden olan $\mathrm{Ca}^{+2}$ iyonlar1 proteinin 1 s1 ile denatürasyonunu önleyen yapıyı stabilize ederek proteaz etkisini önleyebilir (Brockerhoff ve Jensen,1974). Lopes vd., (2002) $\mathrm{Mg}^{+2}$ ve $\mathrm{Mn}^{+2}$ iyonlarının laktik asit bakterilerine ait lipaz enzimlerinin aktivitesini iki üç kat artırdığını saptamışlardır. Araştırıcılar $\mathrm{Hg}^{+2}, \mathrm{Cu}^{+2}$ ve $\mathrm{Ni}^{+2}$ iyonlarının enzim aktivitesini önemli oranda inhibe ettiğini rapor etmişlerdir. Çalışmamızda $\mathrm{Cu}^{+2}$ ve $\mathrm{Ni}^{+2}$ iyonlannın önemli bir etkisi saptanamamıştır. Ramakrishnan vd., (2016) E. faecium'a ait lipaz enzimi aktivitesinin $\mathrm{Na}^{+}, \mathrm{Ca}^{+2}$, $\mathrm{Li}^{+}$ve $\mathrm{Mg}^{+2}$ ile arttığ buna karşıllık $\mathrm{Ba}^{+2}$ in varlığında ise aktivitenin düştüğü bildirilmiştir.

Çizelge 3. Çeşitli katyon ve yüzey aktif maddelerin lipaz aktivitesi üzerine etkisi.

Table 3. The effect of various cations and surfactants on lipase activity.

\begin{tabular}{|c|c|c|c|c|c|}
\hline \multirow{2}{*}{$\begin{array}{l}\text { Uygulama } \\
\text { Application }\end{array}$} & \multicolumn{2}{|c|}{ Kalan aktivite (\%) } & \multirow{2}{*}{$\begin{array}{l}\text { Uygulama } \\
\text { Application }\end{array}$} & \multicolumn{2}{|c|}{$\begin{array}{l}\text { Kalan aktivite (\%) } \\
\text { Remaining activity (\%) }\end{array}$} \\
\hline & E114 11 & E114 & & E114 11 & E114 \\
\hline Kontrol/Control & 100.0 & 100 & EDTA & 105.4 & 99.9 \\
\hline $\mathrm{HgCl}_{2}$ & 45.7 & 42.6 & Üre /Urea & 107.1 & 101.1 \\
\hline $\mathrm{CaCl}_{2}$ & 109.9 & 98.1 & SDS & 90.9 & 81.7 \\
\hline $\mathrm{MnCl}_{2}$ & 120.5 & 97.6 & TritonX-100 & 102.4 & 98.8 \\
\hline $\mathrm{CuCl}_{2}$ & 119.0 & 97.9 & Tween 20 & 94.0 & 100.5 \\
\hline $\mathrm{NiCl}_{2}$ & 103.1 & 99.5 & Tween 80 & 104.6 & 99.6 \\
\hline $\mathrm{KCl}$ & 106.2 & 98.5 & & & \\
\hline $\mathrm{ZnCl} 2$ & 108.0 & 97.4 & & & \\
\hline $\mathrm{MgCl} 2$ & 119.7 & 97.7 & & & \\
\hline
\end{tabular}

Yüzey aktif maddelerden TritonX-100, Tween 20 ve Tween 80 enzimlerin aktivitesinde önemli bir değişikliğe neden olmamıştır. Araşturıcılar Triton X-100 gibi iyonik olmayan surfektanların lipaz aktivitesini indüklediğini ve enzim denatürasyonunu önlediğini bildirmişlerdir (Amid vd., 2015). Tween 80 esasen mikrobiyal lipaz üretimi için önemli bir substrattır. Çalışmada Tween 80 E. durans izolatlanna ait ektrasellüler enzimlerin aktivitesi üzerine önemli bir etkisi olmamıştır. Bulguların aksine Lopes vd., (2002) laktik asit bakterilerine ait enzimlerin aktivitesini Tween 80 'in inhibe ettiğini bildirmişlerdir. Sukohidayat vd., (2018) Tween 20 ve Tween 80'in enzim aktivitesini artırdığını anyonik sürfaktan SDS'in ise enzim aktivitesini inhibe ettiğini bildirmişlerdir.

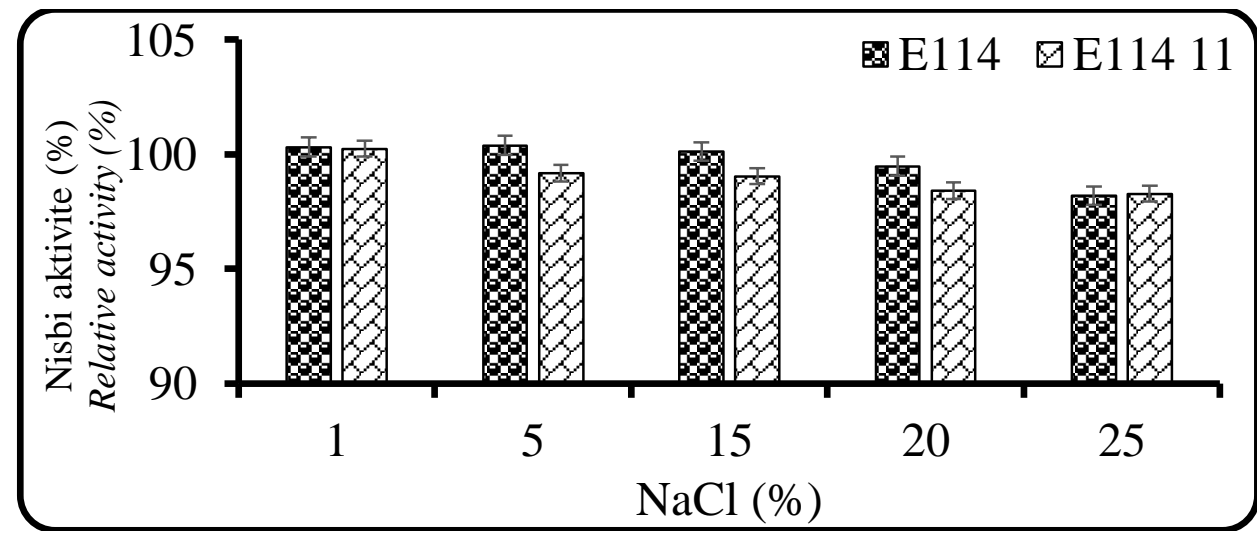

Şekil 8. Kısmi saflaşurılmış ekstraselüler lipaz enziminin aktivitesi üzerine tuzun etkisi Figure 8. Effect of salt on the activity of the partially purified extracellular lipase ensyme 


\section{Enzim aktivitesine tuzun etkisi}

Tuzun etkisi lipaz enzimleri üzerine farklı olmuştur. Enterokoklar ile üretilen lipaz enziminin tuza dirençli olduğu görülmüştür. Her iki E. durans'a ait ekstraselüler enzim halofilik özelliktedir. \%20 tuz içeren ortamda en yüksek aktiviteyi göstermiştir

E. durans'a ait lipaz enzimleri \%25 gibi yüksek tuz konsantrasyonunda bile aktivitesini kaybetmemiştir (Şekil 8). Bu özellikleri gida üretiminde önemli bir özelliktir. Esteban -Torres vd., (2015) L. plantarum'a ait lipaz enzimini halotolerant olduğunu bildirmiştir. Süt ve et ürünlerinin fermantasyonunda tuz tolerans1 önem taşımaktadır. Bu fermantasyonlarda yüksek tuz konsantrasyonu vardır (Bautista-Gallego vd., 2013; Johnson vd., 2009). Peynir yapımında ve olgunlaşmasında tuz ilavesi bulunmaktadır. Ayrıca peynir salamurasına yaklaşık $\% 20$ civarında tuz ilave edilmektedir (Johnson vd., 2009).

\section{SONUÇ}

Laktik asit bakterilerinin lipaz enzimi üretimi diğer lipaz üretici bakterileri ile karşılaştırıldığında daha düşüktür. Bununla birlikte, yüksek laktik asit bakteri sayısı ve aktivitesi fermente et ve süt ürünlerinde önem taşımaktadır. Et ürünlerinde olgunlaşmanın yavaş bir işlem olduğu, düşük aktivitelerin bile hayvan yağı üzerine etki etmesine izin vermesi nedeniyle önem taşımaktadır. Bu şekilde laktik asit bakterilerine ait lipazlann lezzet oluşumu üzerindeki rolü nedeniyle önem taşıyabilir. Süt ürünlerinin oluşumunda tereyağ1 ve peynirde arzu edilen aromanın oluşmasında laktik asit bakterilerinin lipazı önemli bir rol oynayabilir. $\mathrm{Bu}$ özellikleri nedeniyle, bu mikroorganizmalardan izole edilen lipazların araşturlması her yıl artmaktadır (Lopes vd., 2002). E. durans ile üretilen lipaz enzimi $45^{\circ} \mathrm{C}$ de, $\mathrm{pH} 9-10$ da aktivitelerinin yüksek olmasının yanında gidaların $\mathrm{pH}$ 5.0-5.5 gibi asidik koşullarda da aktiviteye sahip olmas1, $55^{\circ} \mathrm{C}$ ye 48 saat gibi bir süre direnç göstermesi ayrıca düşük sıcaklıkta da aktivitesini kaybetmemesi ve halofil özellikleri nedeniyle gida endüstrisinde ümit vaat etmektedir.

\section{ÇIKAR ÇATIŞMASI}

Yazarların makale ile ilgili başka kişiler veya kurumlar ile çıkar çatışması bulunmamaktadır.

\section{YAZAR KATKILARI}

EA, araştırmanın yürütülmesi, değerlendirilmesi ve yazımında, VK lipaz enziminin belirlenmesi ve enzim aktivite çalışmalarında, MK araştırmanın planlanması, değerlendirilmesi ve yazımında görev almıştır.

\section{KAYNAKLAR}

Adrio, J.L., Demain, A.L. (2014). Microbial enzymes: tools for biotechnological processes. Biomolecules, 4(1): 117-139.

Amato, P., Christner, B.C. (2009). Energy metabolism response to low-temperature and frozen conditions in Psychrobacter cryobalolentis. Appl Environ Microbiol, 75, 711-718.

Amid, M., Manap, M., Hussin, M., Mustafa, S. (2015). A novel aqueous two phase system composed of surfactant and xylitol for the purification of lipase from pumpkin (Cucurbita moschata) seeds and recycling of phase components. Molecules, 20(6): 11184-11201.

Aravindan, R., Anbumathi, P., Viruthagiri, T. (2007). Lipase applications in food industry. Int J Biotechnol, 6, 141-158.

Arora, P.K. (2013). Staphylococcus lipolyticus sp. nov., a new cold-adapted lipase producing marine species. Ann Microbiol, 63(3): 913-922.

Bautista-Gallego, J., Rantsiou, K., GarridoFernandez, A., Cocolin, L., Arroyo-Lopez, F.N. (2013). Salt reduction in vegetable fermentation: reality or desire?. Food Sci, 78(8): R1095-R1100.

Bharathi, D., Rajalakshmi, G., Komathi, S. (2018). Optimization and production of lipase enzyme from bacterial strains isolated from petrol spilled soil. King Sand Univ-Sc. https://doi.org/10.1016/j.jksus.2017.12.018.

Bhargavi, P.L., Manjushri, R., Reddy, P.N. (2010). Lipase production by lactic acid bacteria in submerged and solid state fermentation. BTAIJ, 4(3): 126-129.

Bradford, M.M. (1976). A rapid and sensitive method for the quantitation of microgram quantities of protein utilizing the principle of protein-dye binding. Anal Biochem, 72(1-2): 248254. 
Brockerhoff, H. and Jensen, R.G. (1974). Lipolytic Ensymes. Academic Press, NewYork, 340 p.

Choo, D.W., Kurihara, T., Suzuki, T., Soda, K., Esaki, N. (1998). A cold-adapted lipase of an alaskan psychrotroph, Pseudomonas sp. strain B111: Gene cloning and enzyme purification and characterisation. Appl Environ Microb, 64 (2): 486491.

Çitak, S., Yucel, N., Orhan, S. (2004). Antibiotic resistance and incidence of Enterococcus species in Turkish white cheese. Int Dairy Technol, 57(1): 2731.

de Almeida, A.F., Tauk-Tornisielo, S.M. and Carmona, E.C. (2013). Acid lipase from Candida viswanathii: production, biochemical properties, and potential application. BioMed Res Int, ID 435818, 10.

Dellali, A. Karam H.Z., and Karam, N-E. (2020). Lipase and esterase activities of lactic acid bacteria isolated from different biotopes African Biotech, 19(4): 156-164.

Eaton, T.J. and Gasson, M.J. (2001). Molecular screening of Enterococcus virulence determinants and potential for genetic exchange between food and medical isolates. Appl Environ Microbiol, 67(4): 1628-1635.

Enger, E.D., Ross, F.C. and Bailey, D.B. (2012). Concepts in Biology, 14th ed.; McGraw- Hill: New York, NY, USA. 707p.

Esteban-Torres, M., Mancheno, J. M., de las Rivas, B., Munoz, R. (2015). Characterization of a halotolerant lipase from the lactic acid bacteria Lactobacillus plantarum useful in food fermentations. LWT-Food Sci and Technol, 60(1): 246-252.

Franz, C.M., Stiles, M.E., Schleifer, K.H., Holzapfel, W.H. (2003). Enterococci in foods- a conundrum for food safety. Int Food Microbiol, 88(2-3): 105-122.

Giraffa, G. (2003). Functionality of enterococci in dairy products. Int Food Microbiol, 88 (2-3): 215222.

Handwerger, S., Pucci, M.J., Volk, K.J., Liu, J., Lee, M.S. (1994). Vancomycin-resistant
Leuconostoc mesenteroides and Lactobacillus casei synthesize cytoplasmic peptidoglycan precursors that terminate in lactate. J Bacteriol, 176(1): 260264.

Hugas, M., Garriga, M. and Aymerich, M.T. (2003). Functionalty of enterococci in meat products. Int Food Microbiol, 88(2-3): 223-233.

Javed, S., Azeem, F., Hussain, S., Rasul, I., Siddique, M.H., Riaz, M., Afzal, M., Kouser, A., Nadeem, H. (2018). Bacterial lipases: A review on purification and characterization. Prog Biophys Mol Biol, 132, 23-34.

Johnson, M.E., Kapoor, R., McMahon, D.J., McCoy, D.R., Narasimmon, R.G. (2009). Reduction of sodium and fat levels in natural and processed cheeses: Scientific and technological aspects. Compr Rev Food Sci Food Saf, 8(3): 252-268.

Karigar, C.S. ve Rao, S.S. (2011). Role of microbial enzymes in the bioremediation of pollutants: a review. Ensyme Res, ID 805187, 1-11 p.

Ko, W.H., Wang, I.T., Ann, P.J. (2005). A simple method for detection of lipolytic microorganisms in soils. Soil Biol \& Biochem, 37, 597-599.

Kumar, A., Kanwar, S.S. (2012). Lipase production in solid-state fermentation (SSF): recent developments and biotechnological applications. Dyn. Biochem. Process Biotech Mol Biol, 6(1): 13-27.

Laemmli, U.K. (1970). Cleavage of structural proteins during the assembly of the head of bacteriophage T4. Nature, 227, 680-885.

Lopes, M.D.F.S., Leitao, A.L., Regalla, M., Marques, J.F., Carrondo, M.J.T., Crespo, M.T.B. (2002). Characterization of a highly thermostable extracellular lipase from Lactobacillus plantarum. Int Food Microbiol, 76 (1-2): 107- 115.

Meyers, S.A., Cuppett, S.L. ve Hutkins, R.W. (1996). Lipase production by lactic acid bacteria and activity on butter oil. Food Microbiol, 13, 383389.

Petrovic, S.E., Skrinjar, M., Becarevic, A., Vujicic, I.F., Banka, L. (1990). Effect of various carbon 
sources on microbial lipases biosynthesis. Biotech Lett, 12(4): 299-304.

Piatkiewicz, A. (1987). Lipase and esterase formation by mutants of lactic acid streptococci and lactobacilli. Milchwissenschaft, 42(9): 561-564.

Rajendran, A., Palanisamy, A. and Thangavelu, V. (2009). Lipase catalyzed ester synthesis for food processing industries. Brazilian Arc of Biol and Tech, 52(1): 207-219.

Ramyasree, S. and Dutta, J.R. (2013). The effect of process parameters in enhancement of lipase productionby co-culture of lactic acid bacteria and their mutagenesis study. Biocatal Agric Biotech, 2, 393-398.

Ramakrishnan, V., Balakrishnan, B., Rai, A. K., Narayan, B., Halami, P. M. (2012). Concomitant production of lipase, protease and enterocin by Enterococcus faecium NCIM5363 and Enterococcus durans NCIM5427 isolated from fish processing waste. Int Aquat Res, 4, 1- 14.

Ramakrishnan, V., Goveas, L.C., Suralikerimath, N., Jampani, C., Halami, P.M., Narayan, B. (2016). Extraction and purification of lipase from Enterococcus faecium MTCC5695 by PEG/phosphate aqueous-two phase system (ATPS) and its biochemical characterization. Biocatal Agric Biotech, 6, 19-27.

Samad, M.Y.A., Razak, C.N.A., Salleh, A.B., Yunus, W.M.Z., Ampton, K and Basri, M (1989). A plate assay for primary screening of lipase activity. J Microbiol Methods, 9, 51-56.
Sangeetha, R., Geetha, A. and Arulpandi, I. (2008). Optimization of protease and lipase production by Bacillus pumilus SG 2 isolated from an industrial effluent. Internet J Microbiol, 5(2):1-8.

Sharma, D., Sharma, B., Shukla, A.K. (2011). Biotechnological approach of microbial lipase: a review. Biotechnol, 10 (1): 23-40.

Sukohidayat N.H.E., Zarei M., Baharin, B.S., and Manap, M.Y. (2018). Purification and Characterization of Lipase Produced by Leuconostoc mesenteroides subsp. mesenteroides ATCC 8293 using an aqueous two-phase system (atps) composed of triton X-100 and maltitol. Molecules, 23, 1800.

Tanasupawat, S., Phoottosavako, M., Keeratipibul, S. (2015). Characterization and lipolytic activity of lactic acid bacteria isolated from Thai fermented meat. Appl Pharmal Sci, 5 (03): 006-012.

Toole, G. and Toole, S. (2004). Essential AS Biology for OCR. Nelson Thornes Ltd.United Kingdom.280p.

Treichel, H., de Oliveira, D., Mazutti, M. A., Di Luccio, M. D., Oliveira, J. V. (2010). A review on microbial lipases production. Food Bioprocess Tech, 3(2): 182- 196.

Uppada, S.R., Gupta, A.K. ve Dutta, J.R. (2012). Statistical optimization of culture parameters for lipase production from Lactococcus lactis and its application in detergent industry. Int Chem Tech Res, 4(4): 1509-1517. 